\title{
FAMILY OCCURRENCE OF SCHISTOSOMAL HEPATOSPLENOMEGALY AND MATERNAL EFFECT
}

\author{
José Tavares-Neto and Aluizio Prata
}

\begin{abstract}
In this paper we present a study of members of 265 nuclear families, aged six or more. This study is based of family heredograms, and takes into account the clinical form of schistosomiasis observed before treatment with oxamniquine. The probability of occurrence of two or more cases of hepatosplenomegaly is low, notwithstanding the fact that it was observed in 38 families. Even less frequent is the occurrence of three or more cases observed in 17 families $(P=0.002)$. The concentration of the hepatosplenic form was higher among siblings than it was among mothers and children, or fathers and children. It was found to be not significant between husband (father) and wife (mother). These observations reinforce the evidence for the presence of a genetic component in susceptibility to the hepatosplenic form of the disease. In cases in which the mother was hepatosplenic there was a higher incidence of hepatosplenic children; the relative risk was a least five times higher than in those in which the father was the affected member (the maternal effect). In cases where both members were affected by the hepatointestinal form, the risk to the filial generation was similar to that of the population in general. Thus, in the process towards severe forms of schistosomiasis mansoni, pre and post natal factors might be involved.
\end{abstract}

Key-words: Schistosomiasis. Family occurrence. Maternal effect.

The occurrence of two or more cases of schistosomal hepatosplenomegaly in the same nuclear family was first observed in 1958 by Klöetzel 13 in the State of Pernambuco. In a rural area of the State of Minas Gerais, Conceição \& Coura ${ }^{8}$, using a more systematic methodology, verified that the number of families, having two or more members affected by the hepatosplenic (HS) form was much higher than that expected. Such an association was not pointed out by Wahab 26 in Egypt.

To expand these studies, we decided to evaluate the familial occurrence of schistosomal hepatosplenomegaly, in a larger group of patients. We report an investigation of nuclear families, based on data obtained from heredograms and clinical examinations.

\section{MATERIAL AND METHODS}

The study was carried out in a hyperendemic area of schistosomiasis mansoni in the city of Catolândia, ( $12^{\circ}$ Latitude, $44^{\circ} 50^{\prime}$ Longitude, W. Gr.), in the State of Bahia, Brazil. In this region there is no malaria

Faculdade de Medicina do Triângulo Mineiro - UberabaMG and Núcleo de Medicina Tropical e Nutrição - Universidade de Brasília.

Financial support from $\mathrm{CNPq}$ and the Ministry of Health.

Address: Faculdade de Medicina do Triângulo Mineiro Praça Thomaz Ulhoa, 706 - 38025 - Uberaba-MG, Brasil. Recebido para publicação em $3 / 12 / 88$. or kalaazar and the population has been under study since 1976 with regular clinical examinations, quantitative parasitological tests and periodic treatment ${ }^{24}$. In one stool examination (Kato-Katz) $70 \%$ of the population was showed to have eggs of Schistosoma mansoni.

In 1986 all households in the area under study were visited and submitted to clinical examination. At that time a heredogram was made in the presence of the mother, taking into consideration the order of birth, including that of the deceased, stillbirths, and abortions.

All possible information about ancestors and descendents, occurrence of consanguinity, as well as information about the existence of other illnesses in the family were considered. In the few cases where the mother was absent (either by death or change of residence) we interviewed the father and, in his absence, we interviewed the oldest child. All given information was checked in a subsequent visit.

If the HS form of the schistosomiasis mansoni was present at the first clinical examination was noted prior to the use of oxamniquine since this form can be reverted by the therapy 29 . The individual was included in the HS group when the spleen was palpable on the left costal rim or beyond, without inspiration. Usually, the left lobe of the liver was prominent, with a nodular surface ${ }^{18}$. Splenectomised individuals were also included in this group. Other clinical presentations were classified as hepatointestinal (HI). 
For the statistical analysis we used the program system "Statistical Package for the Social Science", or special programs in ALGOL language. In the study of familial recurrence we used the binomial distribution $p$ $(\mathrm{x})=\left(\mathrm{x}^{\mathrm{n}}\right) \mathrm{p}^{\mathrm{x}} \cdot \mathrm{q}^{\mathrm{X}-\mathrm{n}}($ Siegel, 1975).

\section{RESULTS}

Two hundred and seventy one nuclear families (father, mother and children) lived in the 233 homes under study. There was no information on at least $25 \%$ of the members of 6 families. In the remaining 265 families $(97.8 \%)$ there were 1386 members who were 6 years old or older. Members under six were excluded because the HS form has never been reported before age 61419 . Out of 26 families, the father $(n=16)$, the mother $(n=9)$, both $(n=1)$, or children $(n=15)$ had not been physically examined before treatment with oxamniquine.

In relation to the HS form of the schistosomiasis mansoni, no cases were recorded in 193 families $(72.8 \%)$, in 34 families one case was recorded $(12.8 \%)$, and in 38 families (14.4\%), there were two or more cases of hepatosplenomegaly. Among those, 8 families presented four or more cases (table 1).

Table 1 - Distribution of hepatosplenic schistosomotic individuals in nuclear families of different sizes.

\begin{tabular}{|c|c|c|c|c|c|c|c|c|c|c|c|}
\hline \multirow{2}{*}{$\begin{array}{l}\text { Family } \\
\text { size * }\end{array}$} & \multicolumn{11}{|c|}{ n Families } \\
\hline & $\begin{array}{l}\text { number of } \\
\text { severe cases }\end{array}$ & 0 & 1 & 2 & 3 & 4 & 5 & 6 & 7 & 8 & Total \\
\hline 2 & & 43 & 6 & 1 & & & & & & & 50 \\
\hline 3 & & 30 & 4 & 3 & - & & & & & & 37 \\
\hline 4 & & 26 & 3 & 5 & 2 & 1 & & & & & 37 \\
\hline 5 & & 23 & 8 & 3 & 3 & - & - & & & & 37 \\
\hline 6 & & 17 & 2 & 3 & 1 & 3 & - & - & & & 26 \\
\hline 7 & & 19 & 3 & - & 1 & - & - & - & - & & 23 \\
\hline 8 & & 11 & 3 & 2 & - & - & - & 1 & - & - & 17 \\
\hline 9 & & 8 & 2 & 2 & 1 & 1 & - & - & - & - & 14 \\
\hline 10 & & 8 & 2 & 1 & - & 1 & - & - & - & - & 12 \\
\hline 11 & & 3 & 1 & - & 1 & - & - & - & - & - & 5 \\
\hline 12 & & 2 & - & 1 & - & - & - & - & - & 1 & 4 \\
\hline 13 & & 2 & - & - & - & - & - & - & - & - & 2 \\
\hline 14 & & 1 & - & - & - & - & - & - & - & - & 1 \\
\hline Total & & 193 & 34 & 21 & 9 & 6 & - & 1 & - & 1 & 265 \\
\hline
\end{tabular}

(*) Number of family members (father, mother and children, 5 years old and older).

Prior to treatment, the frequency of the schistosomotic hepatosplenomegaly $(56 / 922)$ in individuals residing in the area, and aged 6 or more, was $6 \%$ $(q=0.06)$. Because the same individual might be a parent in one family and a child in another, to avoid counting twice the same person, for the calculation of this frequency we took less than the total of family members $(n=1,386)$.

The average family had 5.2 members $(1,386 / 265)$. Thus, the probability $(P)$ from zero to 5 cases $\left[\mathbf{P}(\mathbf{x})=\left(\mathrm{x}^{\mathrm{n}}\right) \cdot \mathrm{p}^{\mathbf{x}} \cdot \mathrm{q}^{\mathrm{n}-\mathrm{x}}\right]$ is displayed on table 2 along with other family sizes, according to the number of cases $(\geq 2)$ of hepatosplenomegaly observed on Table 1 . The probability of occurrence of two cases of HS in a single family would be statistically unlikely, and even more so the occurrence of three cases $(P=0.0019)$ for families with five members. However, even in a family with 12 members the observation of eight cases had a $P=6,1 \times 10^{-8}$. The occurrence of three cases in these families would have $\mathrm{P}<0.05$.

Table 3 showns that the nuclear families of different sizes had respective numbers of observed families " $n$ " with two or more cases HS that correlated to the expected number $\left(n_{e}\right)$; in this situation, $\mathrm{n}_{\mathrm{o}}$ was 38 . Considering the fact that the expected number of families with two or more cases was equal to 11 , the difference was highly significant $(x / 1=69.14$ $\mathrm{p}<0.00001$ ).

The size of the familial generation (n children above 5 years old per nuclear family) varied from 1 to 12. In 221 of such groups, $176(79.6 \%)$ did not have HS; $16(7.3 \%)$ had one affected member, and 29 (13.1\%) had two cases or more as follows: 2 cases in 18 groups; 3 cases in 5 groups; 4 cases in 4 groups; 5 
Tavares-Neto J, Prata A. Family occurrence of schistosomal hepatosplenomegaly and maternal effect. Revista da Sociedade Brasileira de Medicina Tropical 22: 13-18, jan-mar, 1989.

Table 2 - Expected probability of hepatosplenic (HS) cases, according to the average size of the nuclear family, and the number observed in the different family sizes.

\begin{tabular}{lll}
\hline $\begin{array}{l}\text { Family size } \\
\text { n members }\end{array}$ & $\begin{array}{c}\text { n HS cases } \\
\text { observed }\end{array}$ & Probability $(\mathrm{q}=0.06)$ \\
\hline Average $(=5)$ & 0 & 0.7339 \\
& 1 & 0.2342 \\
& 2 & $0.0299^{*}$ \\
& 3 & $0.0019^{*}$ \\
& 4 & $6.1 \times 10^{-5}$ \\
\hline 2 & 5 & $7.0 \times 10^{-7}$ \\
\hline 3 & 2 & $0.0036^{*}$ \\
\hline 4 & 2 & $0.0102^{*}$ \\
\hline 6 & 2 & $0.0191^{*}$ \\
& 3 & $0.0008^{*}$ \\
& 4 & $1.3 \times 10^{-5}$ \\
\hline 7 & 2 & $0.0422^{*}$ \\
\hline 8 & 3 & $0.0036^{*}$ \\
& 4 & $0.0002^{*}$ \\
\hline 9 & 3 & $0.0059^{*}$ \\
\hline 10 & 2 & $0.0695^{*}$ \\
& 6 & $1.1 \times 10^{*}{ }^{*}$ \\
\hline 11 & 2 & 0.0840 \\
& 3 & $0.0125^{*}$ \\
\hline & 4 & $0.0013^{*}$ \\
\hline
\end{tabular}

(*) Significant: $p<0.05$

Table $3-$ Expected $_{(e)}$ and observed $(o)$ number of families and filial generation of different sizes, for $q=0.06$ with two or more cases of hepatosplenic (HS) form.

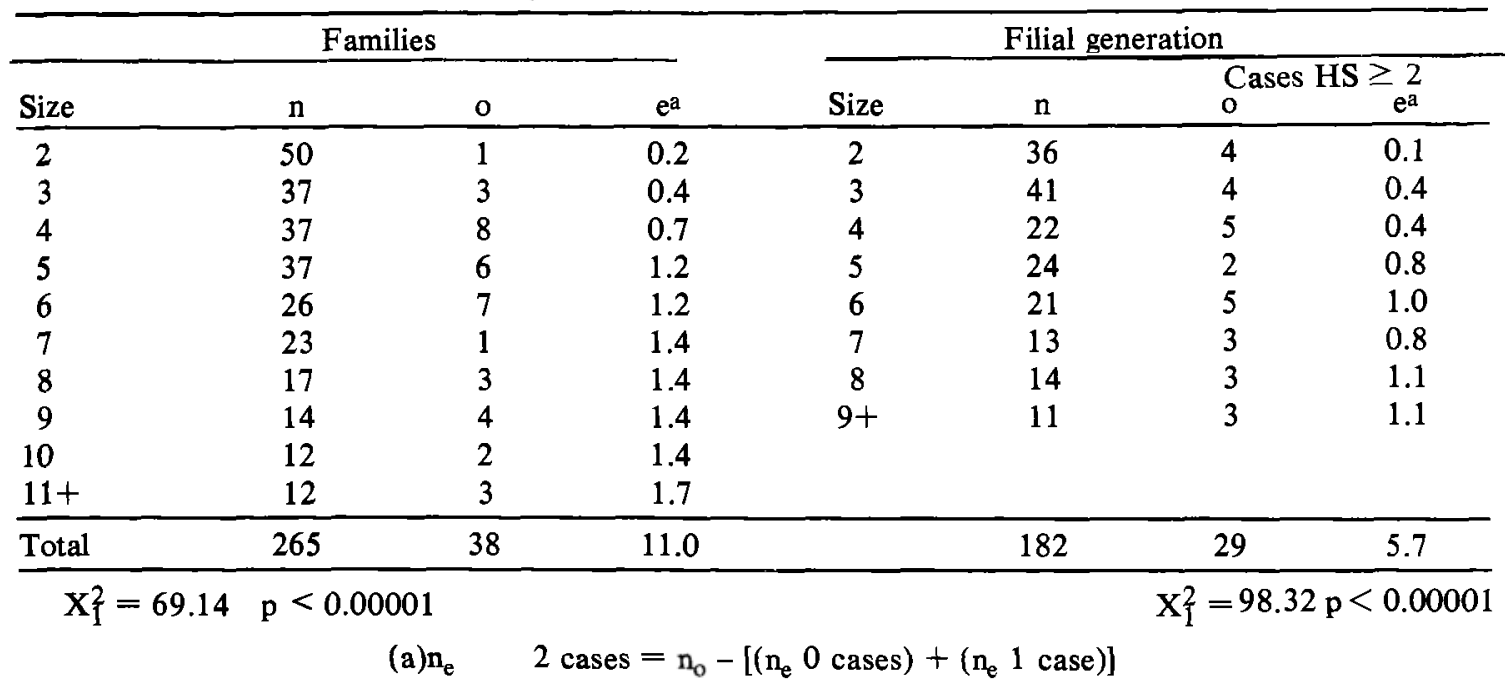


Tavares-Neto J, Prata A. Family occurrence of schistosomal hepatosplenomegaly and maternal effect. Revista da Sociedade Brasileira de Medicina Tropical 22: 13-18, jan-mar, 1989.

cases in 1 group and 8 cases in one group. The probability calculation $q=0.06$, of individuals affected for different sizes of filial groups, presented results similar to those of nuclear families. The expected number of filial groups with two or more cases HS referred to in table 3 was significantly inferior to that observed $\left(x_{1}^{2}=98.32 p<0.00001\right)$.

Familial occurrence was also analysed pairing the clinical forms HI or HS - father/mother; father/ child (father/child 1 ); father/child 2 ; father $/$ child $_{\mathbf{n}}$ ) mother/child; (mother/child $1 .$. ); and sibling/sibling (sibling 1 and sibling; sibling 1 / sibling $_{3}$; sibling / $_{2}$ sibling 3 ...).

In Table 4 the results of these pairings are displayed observing the concentration of schistosomotic hepatosplenomegaly cases between father and children, mother and children, and siblings (siblings and siblings) in a significantly statistical form. A situation of both presenting the clinical form HS was accountable for at least $80 \%$ of the total chi square. Nevertheless between husband and wife (or father and mother) the distribution was random ( $p \geq 0.10$ ).

In Table 4 one can see that the occurrence of the HS form was significantly higher among siblings, reaching a high chi square $\left(x_{1}^{2}=293.44\right)$. Between mother and children $\left(x_{1}^{2}=62.53\right)$, the statistical significance was higher than between father and children $\left(x_{1}^{2}=\right.$ 4.21). On account of this, the couples were divided in the following types as far the clinical form was concerned: "A", both affected by the HI form; "B", HS father and HI mother, " $\mathrm{C}$ " $\mathrm{HI}$, father and HS mother, and " $D$ ", both HS. On table 5, these types of couples were correlated with the children according to the clinical form of the schistosomiasis. The distribution was not equal among the four types of couples $(x\}=$ $85.99 \mathrm{p}<0.00001$ ).

Table 4 - Correlation of clinical forms of schistosomiasis mansoni among members of the nuclear families.

\begin{tabular}{|c|c|c|c|c|c|c|c|c|c|}
\hline \multirow{3}{*}{ Member } & \multirow{3}{*}{ clinical form } & \multicolumn{4}{|c|}{ Mother } & \multicolumn{4}{|c|}{ Children (sibling) } \\
\hline & & \multicolumn{2}{|c|}{$\underline{\mathrm{HS}}$} & \multicolumn{2}{|c|}{ HI } & \multicolumn{2}{|c|}{ HS } & \multicolumn{2}{|l|}{ HI } \\
\hline & & 0 & e & 0 & e & 0 & e & 0 & e \\
\hline $\begin{array}{l}\text { Father } \\
\left(\mathrm{X}_{1}^{2}\right)\end{array}$ & $\begin{array}{l}\text { HS } \\
\text { HI }\end{array}$ & $\begin{array}{r}5 \\
14\end{array}$ & $\begin{array}{c}2.07 \\
16.93 \\
2.62^{\mathrm{a}}\end{array}$ & $\begin{array}{c}21 \\
199 \\
p>0.10\end{array}$ & $\begin{array}{r}23.93 \\
196.07\end{array}$ & $\begin{array}{l}13 \\
66\end{array}$ & $\begin{array}{r}7.82 \\
71.18 \\
4.21\end{array}$ & $\begin{array}{r}69 \\
680 \\
p<0.05\end{array}$ & $\begin{array}{r}74.18 \\
674.82\end{array}$ \\
\hline $\begin{array}{l}\text { Mother } \\
\left(\mathrm{X}_{1}^{2}\right)\end{array}$ & $\begin{array}{l}\text { HS } \\
\text { HI }\end{array}$ & & & & & $\begin{array}{l}20 \\
64\end{array}$ & $\begin{array}{c}4.37 \\
79.63 \\
62.53 \mathrm{a}\end{array}$ & $\begin{array}{c}24 \\
737 \\
\mathrm{p}<0.00001\end{array}$ & $\begin{array}{r}39.63 \\
721.37\end{array}$ \\
\hline $\begin{array}{l}\text { Sibling } \\
\left(\mathrm{X}_{1}^{2}\right)\end{array}$ & $\begin{array}{l}\text { HS } \\
\text { HI }\end{array}$ & & & & & $\begin{array}{l}91 \\
97\end{array}$ & $\begin{array}{r}20.84 \\
167.16 \\
293.44\end{array}$ & $\begin{array}{c}129 \\
1668 \\
p<0.00001\end{array}$ & $\begin{array}{r}199.16 \\
1597.84\end{array}$ \\
\hline
\end{tabular}

(a) Yates correction.

Table 5 - Distribution of hepatosplenic (HS) and hepatointestinal (HI) schistosomiasis mansoni in children, according with the ones found at the parental generations.

\begin{tabular}{|c|c|c|c|c|c|c|c|c|}
\hline & \multicolumn{2}{|l|}{ Couple } & \multicolumn{2}{|c|}{ HS } & \multicolumn{2}{|c|}{ number of children } & \multicolumn{2}{|c|}{ HS } \\
\hline & Father & Mother & $\mathrm{n}_{\mathrm{o}}$ & $n_{e}$ & $\mathrm{n}_{\mathrm{O}}$ & $\mathrm{n}_{\mathbf{e}}$ & $\%$ & $\mathbf{R R}^{\mathbf{a}}$ \\
\hline “A" & HI & HI & 40 & 59.77 & 638 & 618.23 & 5.9 & 1.0 \\
\hline "B" & HS & HI & 10 & 6.44 & 63 & 66.56 & 13.7 & 2.4 \\
\hline "C"C" & HI & $\mathrm{HE}$ & 17 & 3.09 & 18 & 31.91 & 48.6 & 14.6 \\
\hline "D" & HS & $\mathrm{HE}$ & 3 & 0.70 & 5 & 7.30 & 37.5 & 9.3 \\
\hline
\end{tabular}

(a) Risk as related to the population $(56 / 922)$.

In cases where one of the parents or both had the HS form, there was a significantly, higher occurrence of HS children. Between couples " $C$ " and " $D$ " the frequency of HS children was similar $\left(x_{1}^{2}=0.49 p>\right.$
0.40 ; c. Yates). On comparison with the couples " $B$ " the difference was highly significant $\left(\mathrm{x}_{1}^{2}=15.20 \mathrm{p}<\right.$ $0.0005)$. On the other hand, couples " $B$ " also differed from couples " $\mathrm{A}$ " $\left(\mathrm{x}_{1}^{2}=6.45 \mathrm{p}<0.02\right)$. These 
observations have correlation with the relative risks of hepatosplenomegaly in children from each type of couple. While the risk to the children of couples " $C$ " and " $D$ " was of 13.4 , that of couples " $B$ " was of 2.4 , and that of couples " $A$ " was similar to the risk of the population in general. Thus, the risk of having HS children was higher when one of the parents was HS. This risk is at least five times higher when the mother (as compared to the father) is affected by this serious form of the disease.

\section{DISCUSSION}

In Brazil the HS form of the schistosomiasis mansoni occurs with much higher frequency in whites than in blacks 5202425 . The mestizo, children of black and white parents, show an intermediary frequency, which is significantly inferior than that observed in white individuals 24 . However, in Brazil the whites have better social and economic standards, including a higher rate of literacy16 2224 . This fact would lead us to expect an inverted observation. Findings such as these corroborated the participation of a genetic component in the susceptibility to the HS form of schistosomiasis mansoni 15 .

The occurrence of this severe form was present significantly in the filial generation. In average families, the occurrence of two HS cases would be remote, and the occurrence of three or more cases would be a very rare eventuality indeed. For example, in an average family of five, with $q=0.06$, the probability of having three or more severe cases would be 0.002 . When $q=0.19$ the probability is below (5\%). However, eight families presented four or more cases for $\mathrm{q}=0.06$; the probability would be $6.1 \times 10^{-5}$. If the average size of the family were 10 and $q=0.14$, the probability of having four cases would be inferior to $0.04(4 \%)$. Nevertheless we observed 38 families with two or more cases; 17 families having three or more cases.

In infectious parasitic diseases of low frequency $(<1 \%)$ the probability of contagion among members of the same family is higher than that among unrelated members; extra familial infection foci have a higher probability of influence when the frequency is higher $(>1 \%)$. However, in the latter case, when the affected members are not evenly distributed within the families, we can assune the existence of genetic factors exerting influences in susceptibility to the disease (Beiguelman 1983) 1 as observed in our results and in those of Klöetzel13, and Conceição and Coura ${ }^{8}$.

Intrafamilial environmental factors are influential. However, if these alone were preponderant, or the only relevant ones, the distribution of the HS forms would be uniform among families. The highly signi- ficant concentration of HS cases between children of the same nuclear family favors the hypothesis of the contribution of a genetic factor in the predisposition to the serious forms. This hypothesis is reinforced by the existence of concentration among parents and children, and by the fact that a concentration among the parents themselves was not observed.

A very interesting verification was that of a higher concentration of $\mathbf{H S}$ children, when the mother was the one affected by the same clinical form of the disease. In Taquarandi-Bahia, Prata, Bina, Saturnino and Tavares-Neto (umpublished data) have also observed this maternal effect. There is no reported research focusing on this maternal effect.

In man this effect, as in mammals in general, has been studied with emphasis on its quantitative characteristics 10 .

The pre and post-natal influences would be the basis for the maternal effect, and they certainly would involve several factors. Camus e $\mathrm{col}^{3}$., for example, verified that children, not affected by Schistosoma mansoni, but whose mothers were infected, responded more significantly to the intradermic delayed test with adult worm antigen. This seems to be due to intrauterine sensibilisation to schistosomal antigens or through the milk ${ }^{3}$. Later on, Camus et $\mathrm{al}^{4}$, and Ohta et al ${ }^{17}$, noted that these immunological characteristics were related to the hepatosplenic form of the disease. Perhaps, due to this, the HS mothers showed a higher incidence of HS children. However, Sobral et al 23 ., verified experimentally that mice, born of infected females, showed a higher resistence to infection induced after weaning.

However factors involved in the susceptibility and in the resistence to schistosomal infection, and to the HS of the disease, should be distinguished. For this purpose, when investigating the factors predisposing to infection and to HS disease, one must take into account items such as environmental and pre and post-natal factors, besides those an exclusive environmental nature.

\section{RESUMO}

As formas clinicas da esquistossomose mansônica, anteriores ao tratamento com oxamniquine, foram estudadas nos membros de 265 familias, com seis anos ou mais de idade. A probabilidade da ocorrência de dois ou mais casos, na mesma familia, da hepatosplenomegalia esquistossomótica (HE) é baixa, no entanto foi observada em 38 familias; menor probabilidade $(P=0,002)$ devia ocorrer três ou mais casos, porém dezessete famillias estavam nesta situação. A concentração da forma $H E$ foi alta entre irmãos, comparativamente à observada entre 
Tavares-Neto J, Prata A. Family occurrence of schistosomal hepatosplenomegaly and maternal effect. Revista da Sociedade Brasileira de Medicina Tropical 22: 13-18, jan-mar, 1989.

mães e filhos e pais e filhos. Não sendo significante a concentração encontrada no casal entre marido $e$ mulher. Estas observações reforçam a evidência do efeito do componente genético da'susceptibilidade para a forma $H E$. Também, quando a mãe era hepatosplênica (HE) a prevalência desta forma nos filhos foi maior; o risco relativo foi cinco vezes superior (efeito materno), comparado ao encontrado quando era o pai hepatosplênico. Quando ambos os genitores eram hepatointestinal os riscos relativos da forma $H E$, nos filhos, foi semelhante ao da população geral. Assim, provavelmente fatores pré e pósnatais também estarāo envolvidos na predisposição da forma hepatosplênica.

Palavras-chaves: Esquistossomose. Recorrência familial. Efeito materno.

\section{REFERENCES}

1. Beiguelmann B. Leprosy and genetics: a review. Revista Brasileira Genética 6: 109-172, 1983.

2. Bina JC, Prata A. Regressão da hepatosplenomegalia pelo tratamento especifico da esquistossomose. Revista da Sociedade Brasileira de Medicina Tropical 16: 213 218, 1983.

3. Camus D, Carlier Y, Bina JC, Borojevic R, Prata A, Capron A. Sensibilization to Schistosoma mansoni antigen in a infected children born to infected mothers. Journal of Infectious Diseases 134: 405-408, 1976.

4. Camus D, Carlier Y, Capron M, Bina JC, Figueiredo JFN, Prata AR, Capron A. Immunological studies in human schistosomosis III. Immunoglobulin levels, antibodies and delayed hipersensitivity. American Journal of Tropical Medicine and Hygiene 26: 482-490, 1977.

5. Cardoso W. A esquistossomose mansônica no negro. Medicina, Cirurgia e Farmácia 202/203: 89-95, 1953.

6. Cheever AW. A review. Schistosoma japonicum: The pathology of experimental infection. Experimental Parasitology 59: 1-11, 1985.

7. Cheever AW, Dunn MA, Dean DA, Duvall R. Differences in hepatic fibrosis in ICR, C3H, and C57 8L/6 mice infected 3 with Schistosoma mansoni. American Journal of Tropical Medicine and Hygiene 32: 13641369, 1983.

8. Conceição MJ, Coura JR. Ocorrência familiar de esplenomegalia esquistossomática em uma àrea rural de Minas Gerais. Revista da Sociedade Brasileira de Medicina Tropical. 13: 17-20, 1980.

9. Dietze R, Prata A. Rate of reversion of hepatosplenic schistosomiasis after specific therapy. Revista da Sociedade Brasileira de Medicina Tropical 19:69-73, 1986.

10. Falconer DS. Introdución a la genética quantitativa. Ed. Co. Continental, 1971.
11. Fanning MM, Kazura JW. Genetic-linked variation in susceptibility of mice to schistosomiasis mansoni. Parasite Immunology 6: 95-103, 1984.

12. Fanning MM, Peters PA, Davis RS, Kazura JW Mahmoud AAF. Immunopathology of murine infection with Schistosoma mansoni: Relationship of genetic background to hepatosplenic disease and modulation. Journal of Infectious Diseases 144: 148-153, 1981.

13. Klöetzel K. A sindrome hepatosplênica na esquistossomose mansônica. Consideraçōes sobre a incidència familial. Revista Brasileira de Medicina 15: 263-265, 1958.

14. Klöetzel K. Splenomegaly in schistosomiasis mansoni. American Journal of Tropical Medicine and Hygiene 11: 472-476, 1962.

15. Mahomoud AAF. Genetic of schistosomiasis. In: Michal F (Ed.) Modern genetic concepts and techniques in the study of parasites. Co. Ag. Basel, p. 302-303, 1981.

16. Oliveira LEG, Porcaro RM, Araújo TCN. O lugar do negro na força de trabalho. Instituto Brasileiro de Geografia e Estatística (IBGE), Rio de Janeiro, 88p., 1981.

17. Ohta N, Nishimura YK, Iuchi M, Sasazuki T. Immunogenetic analysis of patients with post-schistosomal liver cirrhosis in man. Clinical Experimental Immunology 49: 493-499, 1982.

18. Prata A. Como caracterizar a forma hepatosplênica da esquistossomose. In: Prata A, Aboim E. (ed.), II Simpósio sobre Esquistossomose, Salvador, Bahia, p. 179$184,1970$.

19. Prata A, Bina JC. Development of the hepatosplenic form os schistosomiasis. Gazeta Médica da Bahia. 68: 49-60, 1968.

20. Prata A. Schroeder S.A comparison of whites and negroes infected with Schistosoma mansoni in hyperendemic areas. Gazeta Médica da Bahia 67: 93-98, 1967.

21. Siegel S. Estatistica não-paramétrica, McGraw-Hill, p. $350,1975$.

22. Silva NV. Cor e o processo de realizaçăo sócio-econômica. Revista de Ciências Sociais 24: 391-409, 1981.

23. Sobral ACL, Lenzi JA, Lenzi HL. Influência de fatores congênitos e do aleitamento na evolução da infecção esquistossomótica. Revista da Sociedade Brasileira de Medicina Tropical 10 (supl.): 64, 1987.

24. Tavares-Neto J. Recorrência familial e composição racial na esquistossomose mansónica. Tese de Mestrado, Universidade de Brasilia, 256p., 1987.

25. Tavares-Neto J. A raça branca e a forma hepatosplênica da esquistossomose. Revista de Saúde Pública 21: 342$347,1987$.

26. Wahab AMF. Clinical features of hepatosplenic schistosomiasis in Egypt. World Health Organization, (Who Expert Committe), 1984. 